\title{
En kvinne med feber, røde øyne og utbredt utslett
}

\author{
En kvinne i 70-årene ble innlagt i medisinsk avdeling med spørsmål om \\ allergi. Hun hadde feber, frostanfall, muskel- og leddsmerter, kløende \\ utslett og bilateral konjunktival injeksjon. Det ble en langvarig innleg- \\ gelse med et livstruende forløp.
}

Øyvind Magne Bremnes oyvind.bremnes@unn.no Øystein Grimstad Katja Eskeland Bremnes Nevro-, hud-og revmatologisk avdeling Universitetssykehuset Nord-Norge
Kvinnen $i$ 70-årene ble akuttinnlagt $i$ medisinsk avdeling på grunn av mistanke om en allergisk reaksjon. Syv dager tidligere hadde hun fått feber, med en temperatur på $39^{\circ} \mathrm{C}$, frostanfall, muskel- og leddsmerter og kløende utslett på øvre del av rygg og brystkasse. Hun kunne fortelle at hun hadde malt huset dagen før sykdomsdebuten.

Utslettet spredte seg i løpet av få dager til å involvere størsteparten av truncus og overog underekstremiteter. I tillegg fikk hun bilateral konjunktival injeksjon, hodepine, tørrhoste og et vekttap på $5 \mathrm{~kg}$ i dagene frem mot innleggelsen.

Hun hadde flere besøk hos primærlege $i$ dagene før hun ble innlagt. Det var forsøkt behandling med paracetamol, paracetamol/ kodein og deksklorfeniramin $2 \mathrm{mg} \times 3$ - uten effekt. På grunn av hypertensjon og transitorisk iskemisk attakk halvannet àr tidligere brukte hun acetylsalisylsyre $75 \mathrm{mg} \times 1$, dipyridamol retard $200 \mathrm{mg} \times 2$, nifedipin depot $30 \mathrm{mg} \times 1$ og enalapril/hydroklortiazid $20 \mathrm{mg} /$ $12,5 \mathrm{mg} \times 1$. De siste to ukene hadde hun også brukt allopurinol $300 \mathrm{mg} \times 1$ grunnet smerter $i$ venstre stortå og forhøyet urinsyrenivå i serum på $489 \mu \mathrm{mol} / \mathrm{l}$ (referanseverdi 155-400 $\mu \mathrm{mol} / \mathrm{ll}$. Hun hadde kjent nikkelallergi og ved en tidligere anledning angivelig reagert på penicillin med utslett.

Ved ankomst sykehuset var blodtrykket 148/84 $\mathrm{mm} \mathrm{Hg}$, pulsen $100 \mathrm{slag} / \mathrm{min}$ regelmessig, temperaturen målt aksillært $40,2^{\circ} \mathrm{C}$, respirasjonsfrekvensen 20/min, saturasjonen normal. Hun hadde et rødlig makuløst konfluerende utslett over hals og truncus som lot seg avbleke ved trykk. I tillegg fant man en $1 \mathrm{~cm}$ stor blemme under den ene fotsålen. Pasienten hadde bilateral konjunktival injeksjon med gulaktig puss.

Blodprøver viste hemoglobin $13,1 \mathrm{~g} / 100 \mathrm{ml}$ (referanseverdi 11,5-16,0 g/100 ml), leukocytter $4,8 \cdot 10^{9} / \mathrm{l}\left(4,0-11,0 \cdot 10^{9} / \mathrm{l}\right)$, eosinofile celler $0,3 \cdot 10^{\%} / \mathrm{l}\left(0,0-0,5 \cdot 10^{9} / \mathrm{l}\right)$, trombocytter $258 \cdot 10^{9} / \mathrm{l}\left(150-450 \cdot 10^{\%} / \mathrm{l}\right)$, senkningsreaksjon $38 \mathrm{~mm} / \mathrm{t}(3-28 \mathrm{~mm} / \mathrm{t})$, C-reaktivt protein $6 \mathrm{mg} / \mathrm{l} /<5 \mathrm{mg} / \mathrm{ll}$, aktuell bikarbonat $23 \mathrm{mmol} / \mathrm{l}(22-26 \mathrm{mmol} / \mathrm{l})$ og glukose 6,2 $\mathrm{mmol} / \mathrm{l}(4,2-6,3 \mathrm{mmol} / \mathrm{l})$.

Lege ved medisinsk avdeling vurderte som tentative diagnoser influensa, Stills sykdom ivoksen alder («adult Still's disease», en medisinsk tilstand som karakteriseres ved feber, leddbetennelser og forbigående lakserødt makuløst eller makulopapuløst utslett) eller vaskulitt. Pasienten ble isolert, og det ble tatt virusprøver, blodkulturer, urinstiks og dyrking av urin, svelg- og øyesekret, pneumokokkantigen $i$ urin og røntgen thorax.

Hudlege i hjemmevakt ble kontaktet telefonisk dagen etter innleggelsen. Utslettet skal da ha blitt beskrevet som avblekbart, uten blemmer eller slimhinneaffeksjon, og tilsyn den påfølgende dag ble avtalt.

Ved nylig oppstått avblekbart erytematøst makuløst utslett og feber er vanligste differensialdiagnose reaktivt utslett som ledd i infeksjon. Legemiddelutslett skal alltid vurderes hos pasienter som tar eller nylig har tatt et legemiddel og utvikler utslett. Kombinert med vekttap må malignitet utelukkes dersom ikke annen årsak blir funnet.

Infeksjonsmedisiner fant ingen grunn til å til å tro at det var en infeksjon, og isolasjonen ble opphevet. Medikamentelt betinget utslett ble regnet som mest sannsynlig. Foruten allopurinol hadde pasienten ikke startet med nye medikamenter utover det som var forskrevet fra primærlegen etter debut av feber og utslett. Kvinnen brukte heller ingen naturmedisiner. Allopurinol ble seponert i påvente av hudlegetilsyn. Over natten ble tilstanden ytterligere forverret, i form av temperatursvingninger, økt blemmedanning og smerter i huden.

Pasienten hadde to dager etter innleggelsen et sammenflytende makuløst erytem over størsteparten av hudoverflaten (fig 1). Det var store blemmer på $10 \times 4 \mathrm{~cm}$ under begge fotsåler og mange mindre blemmer på under $1 / 2 \mathrm{~cm}$ i diameter under begge bryster og på lateralsiden av overarmene. Hun hadde konjunktival injeksjon med gulaktig pussdanning bilateralt samt utbredt erytem på leppene og i munnhulen, gule kruster på leppene og hvitt belegg med enkelte fissurer på tungen. Hudlege mistenkte StevensJohnsons syndrom (SJS) eller toksisk epidermal nekrolyse (TEN) under utvikling. 


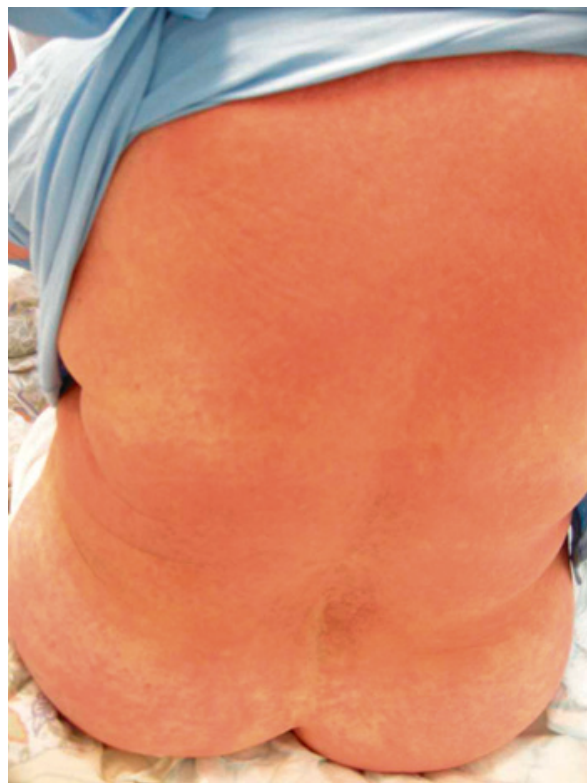

Figur 1 Ved innkomst hadde pasienten et utbredt erytematøst makuløst utslett. Bildet viser rygg, de øvrige hudområder hadde samme kliniske bilde

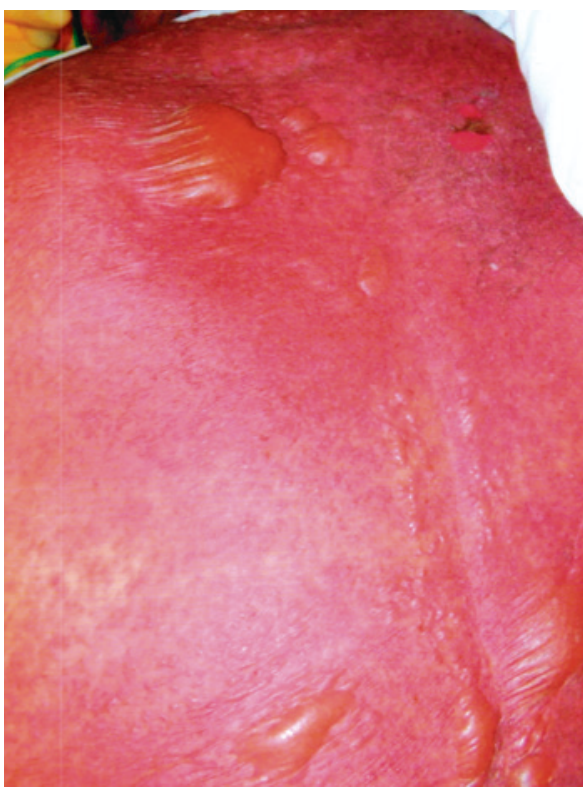

Figur 2 I løpet av de første dagene etter innleggelsen ble det hissigere og mer sammenflytende erytemer samt økende blemmedanning. Bildet viser rygg og nakke, de øvrige hudområder hadde samme kliniske bilde

Stevens-Johnsons syndrom og toksisk epidermal nekrolyse utgjør samme tilstand med ulik alvorlighetsgrad (1). Den kalles StevensJohnsons syndrom dersom $<10 \%$ av hudoverflaten er affisert med epidermal løsning, toksisk epidermal nekrolyse er betegnelsen dersom $>30 \%$ av hudoverflaten er affisert. Dersom 10-30\% av hudoverflaten er affisert, betegnes tilstanden «SJS-TEN-overlapping».

Sykdommen karakteriseres av en prodro- malfase på 1-3 dager med feber, ubehag i øynene og smerter i svelget. Deretter opptrer mørkerøde eller purpuriske makler i forskjellig størrelse og form med påfølgende løsning av epidermis fra dermis med blemmedanning og erosjoner. Slimhinnene er nesten alltid affisert (2). Øyeaffeksjon forekommer hos inntil $88 \%$ og kan være alvorlig (3).

Medikamenter er vanligste årsak til Stevens-Johnsons syndrom og toksisk epidermal nekrolyse, og oftest skyldes det medikamenter der inntaket startet 1-4 uker tidligere. Tilstanden kan også forårsakes av medikamenter pasienten har brukt i lengre tid. Infeksjoner er sjeldnere årsak til Stevens-Johnsons syndrom og toksisk epidermal nekrolyse (2). Vår pasient hadde to uker før det aktuelle startet med allopurinol. Det var dermed mest sannsynlig at dette medikamentet var årsaken til hennes akutt innsettende sykdom.

Alle medikamenter kvinnen sto på fra tidligere, ble seponert. Det ble tatt hudbiopsier til histologisk undersøkelse og immunfluorescensundersøkelse. Man startet behandling i form av humant normalt immunoglobulin $1 \mathrm{~g} / \mathrm{kg}$ kroppsvekt daglig $i$ tre påfølgende dager, rikelig med intravenøs væske og smertestillende.

For å sikre intravenøs tilgang fikk hun innlagt sentralvenøst kateter. Samtidig ble det bemerket økende blemmedanning $i$ huden (fig 2), tyngre pust og økende smerter $i$ munnhulen (fig 3). For å sikre luftveiene og sørge for bedre monitorering ble hun sedert, intubert og overflyttet intensivavdelingen. Brannskadeavdelingen ved Haukeland universitetssykehus ble kontaktet med spørsmål om overflytting for videre behandling der, men dette ble avslått.

Brannskadeavdelingen ved Haukeland universitetssykehus har landsfunksjon for behandling av brannskader og brannskaderelaterte tilstander. Stevens-Johnsons syndrom og toksisk epidermal nekrolyse regnes som brannskaderelaterte tilstander som krever spesialisert overvåkning og behandling. Studier har vist økt overlevelse etter behandling ved spesialiserte brannskadeavdelinger (4), men dette er usikkert (5).

De påfølgende dager progredierte tilstanden ytterligere. På dag 7 etter innleggelsen ble det anslått at $90 \%$ av hudoverflaten var affisert med blemmer og erosjoner (fig 4). All løs hud og rester av blemmetak ble forsiktig fjernet med lett skrubbing med klorheksidinglukonat og skylling med saltvann, i samarbeid med plastikkirurg. Tilnærmet hele kroppsoverflaten ble dekket med ulike skumbandasjer, vattfôring og elastiske bind.

Mikroskopisk undersøkelse av hudbiopsier viste subepidermal vesikulering med lichenoid reaksjon og cytoide celler $i$ alle lag av epidermis og fokuser med begynnende epidermal nekrose. Direkte immunfluorescensundersøkelse viste intraepidermale cytoide celler positive for immunglobulin $\mathrm{G}$ og immunglobulin M samt komplement C3. De histologiske forandringene og immunfluorescensfunn var forenlige med Stevens-Johnsons syndrom og toksisk epidermal nekrolyse.

Hudbiopsi for histopatologisk undersøkelse og immunfluorescens er nyttig i diagnostikken, og kan være til hjelp for å skille StevensJohnsons syndrom og toksisk epidermal nekrolyse fra andre akutte blemmesykdommer, slik som stafylokokkindusert subkorneal hudløsning (staphylococcal scalded skin syndrome/SSSS), pemfigus og akutt generalisert eksematøs pustulose (AGEP).

Erythema multiforme kan være vanskelig å skille fra Stevens-Johnsons syndrom og toksisk epidermal nekrolyse histopatologisk, men det er ofte mer dermal inflammasjon og mindre epidermal nekrolyse ved erythema multiforme (2).

Pasienten fikk økende behov for sirkulasjonsstøttende behandling med pressor og væske for å holde blodtrykket adekvat. Hun ble behandlet med høy dose noradrenalin over $0,4 \mathrm{mcg} / \mathrm{kg} / \mathrm{min}$ og Ringer-acetat 500 $\mathrm{ml} / \mathrm{t}$. På dag 7 etter innleggelsen ble hun oppfattet som septisk og man startet behandling med klindamycin $600 \mathrm{mg} \times 3$, gentamicin 400 $\mathrm{mg} \times 1$ og la til hydrokortison $100 \mathrm{mg} \times 3 \mathrm{som}$ binyrebarksubstitusjon.

Det var oppvekst av Eschericia coli i urinen, gule stafylokokkeriekspektorat og hvite stafylokokkerisårsekret og iøyesekret i prøver tatt noen dager tidligere. Blodkultur tatt ved flere anledninger ga ingen oppvekst av bakterier.

I forløpet utviklet hun ulike elektrolyttforstyrrelser, kreatinfosfokinase- og myoglobinstigning på henholdsvis 1000 IE/L (35-210 IE/L) og $7732 \mu / l<60 \mu / l)$, leversvikt og nyresvikt, sistnevnte behandlet med kontinuerlig venovenøs hemofiltrasjon. Hun ble også trakeostomert grunnet behov for langvarig respiratorbehandling.

Utviklingen snudde tiende innleggelsesdøgn, da det kunne observeres begynnende reepitelialisering. 14 dager etter innleggelsen ble det estimert at $50 \%$ av huden var leget. Fra dag 18 begynte man å redusere sederingen. Dag 34 ble hun flyttet fra intensivavdelingen og dag 49 etter innleggelsen ble hun utskrevet til et rehabiliteringssenter. Hud og slimhinner var da fullstendig tilhelet, nærmest uten sekveler, bortsett fra kløe og tørrhet.

Ved kontroll tre måneder etter utskrivning var huden tilnærmet normalisert. Hun hadde lett hudkløe, ubehag $i$ arret etter trakeosto- 


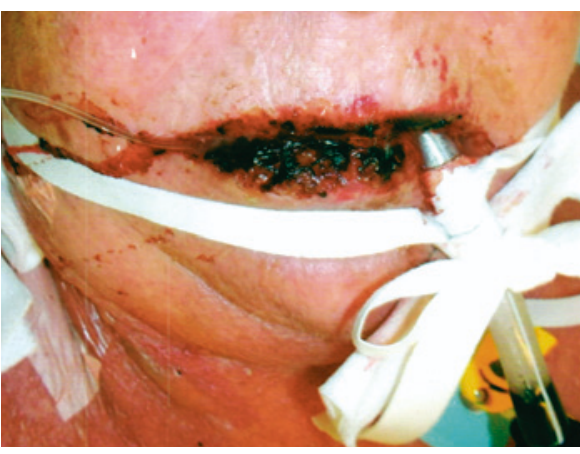

Figur 3 Det utviklet seg uttalt keilitt med erosjoner og kruster. For øvrig var det utbredte sammenflytende erytemer og blemmer på halsen

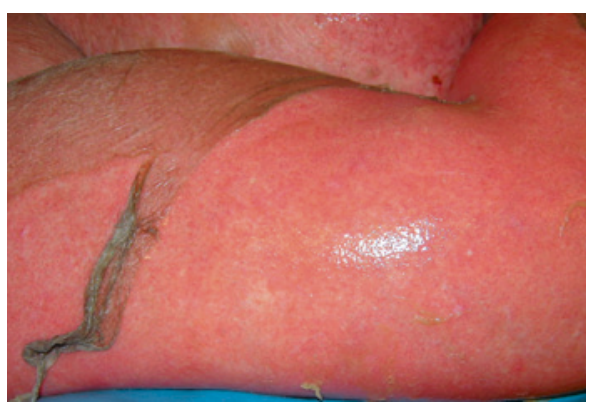

Figur 4 På dag 7 etter innleggelsen ble det anslått at $90 \%$ av hudoverflaten var dekket av blemmer og erosjoner. Her et nærbilde av høyre overarm

mien og tørre øyne, med behov for fuktighetsgivende øyedråper.

\section{Diskusjon}

Alvorlig kutan medikamentreaksjon må alltid mistenkes hos pasienter med blemmer i huden, slimhinneaffeksjon og eventuelt tillegg av symptomer på nedsatt allmenntilstand.

Kutane medikamentreaksjoner er vanlig og affiserer $2-3 \%$ av dem som er innlagt $i$ sykehus (6). De fleste medikamentreaksjoner regnes som mindre alvorlige, hvorav makulopapuløse medikamentreaksjoner er vanligst.

De alvorlige medikamentreaksjonene er blant annet Stevens-Johnsons syndrom, toksisk epidermal nekrolyse, legemiddelreaksjon med eosinofili og systemsymptomer (drug reaction with eosinophilia and systemic symptoms, DRESS), akutt generalisert eksematøs pustulose, erytrodermi og anafylaksi. Tidlig i forløpet kan de alvorlige medikamentreaksjonene vise seg som et makulopapuløst utslett og kan være vanskelig å skille fra mindre alvorlige medikamentreaksjoner. I en studie fra 2015 fant man at alder, latenstid fra oppstart av medikament til debut av utslett, smerte i huden, slimhinneaffeksjon og bruk av antiepileptika var assosiert med utvikling av alvorlig medikamentreak- sjon hos dem som initialt hadde et makulopapuløst utslett (7).

Stevens-Johnsons syndrom og toksisk epidermal nekrolyse er akutte og potensielt livstruende tilstander. Individer fra alle raser og i alle aldre rammes, kvinner noe hyppigere enn menn. Sykdommen er sjelden. Årlig innsidens av Stevens-Johnsons syndrom er 1,2-6 per million, for toksisk epidermal nekrolyse er den $0,4-1,2$ per million (8).

Medikamentbruk er den vanligste årsaken til Stevens-Johnsons syndrom og toksisk epidermal nekrolyse, og over 200 ulike medikamenter er identifisert som utløsende faktor. Et mindretall av tilfellene kan ikke klart tilskrives et medikament og kan ha andre årsaker, blant annet infeksjoner med Mycoplasma pneumoniae (9).

Sykdommens patogenese er ikke fullstendig klarlagt. Metabolitter av legemidler eller mikrobiologiske agenser induserer en immunrespons. Cytotoksiske T-celler aktiveres med økt cytokinproduksjon. Dette fører til massiv apoptose av keratinocytter (2). Mortaliteten er høy - $24 \%$ ved Stevens-Johnsons syndrom og $49 \%$ ved toksisk epidermal nekrolyse i en studie fra 2013. Grad av epidermal løsning anses som viktigste prognostiske faktor (5).

Ved Stevens-Johnsons syndrom og toksisk epidermal nekrolyse er hurtig seponering av utløsende medikament viktig (10). Utover adekvat væske-/elektrolyttbehandling og annen støttende behandling, hudstell og smertelindring er det ingen etablert terapi ved disse tilstandene. Immunmodulerende og/eller supprimerende behandling, inkludert kortikosteroider, humant normalt immunoglobulin, ciklosporin, plasmaferese og tumornekrosefaktorhemmere, har vært forsøkt. Ingen av disse har dokumentert sikker effekt. Vår pasient ble gitt normalt humant immunglobulin (11). Granulocyttkolonistimunerende faktor har i den senere tid vært brukt $\mathrm{i}$ behandlingen av toksisk epidermal nekrolyse (12).

Allopurinol er den hyppigste årsaken til medikamentindusert Stevens-Johnsons syndrom og toksisk epidermal nekrolyse (13). Medikamentet er det hyppigst brukte uratsenkende preparatet (14). Allopurinolhypersensitivitetsreaksjoner er vanlig. I huden kan det manifestere seg som både alvorlige og mindre alvorlige medikamentreaksjoner. Allopurinol kan også gi feber, vaskulitt, forverret nyrefunksjon, hepatocellulær skade og eosinofili. Nyresvikt og bruk av diuretika gir økt bivirkningsforekomst $(15,16)$.

Andre medikamenter som gir spesielt høy risiko for Stevens-Johnsons syndrom og toksisk epidermal nekrolyse er nevirapin, lamotrigin, karbamazepin, fenytoin, fenobarbital, antibakterielle sulfonamider, sulfasalazin og oksikamer (17).
Vi konkluderte med at vår pasient hadde en alvorlig reaksjon på allopurinol. Da hudlege undersøkte pasienten, var diagnosen lett å stille på bakgrunn av anamnese og kliniske funn. Forut for dette hadde hun hatt feber og utslett i ni dager og var undersøkt av flere leger. Kasuistikken illustrerer hvordan en medikamentreaksjon kan utvikle seg dersom den ikke raskt gjenkjennes og medikamentet seponeres.

Pasienten har gitt samtykke til at artikkelen og bildene blir publisert.

Vi takker alle som var med i diagnostikk og behandling av pasienten, spesielt Silje Fismen for gjennomgang av histologisk undersøkelse.

\section{Øyvind Magne Bremnes (f. 1984)}

er lege i spesialisering.

Forfatter har fylt ut ICMJE-skjemaet og oppgir ingen interessekonflikter

\section{Øystein Grimstad (f. 1972)}

er spesialist i hud- og veneriske sykdommer, ph.d. og overlege.

Forfatter har fylt ut ICMJE-skjemaet og oppgir ingen interessekonflikter

\section{Katja Eskeland Bremnes (f. 1973)}

er spesialist i hud-og veneriske sykdommer og overlege.

Forfatter har fylt ut ICMJE-skjemaet og oppgir ingen interessekonflikter

Litteratur

1. Roujeau JC. Stevens-Johnson syndrome and toxic epidermal necrolysis are severity variants of the same disease which differs from erythema multiforme. J Dermatol 1997; 24: 726-9.

2. French LE, Prins C. Erythema Multiforme, Stevens-Johnson Syndrome and Toxic Epidermal Necrolysis. I: Bolognia JL, Jorizzo JL, Schaffer JV et al, red. Dermatology. 3. utg. Amsterdam: Elsevier Saunders, 2012: 323-333.

3. Kohanim S, Palioura S, Saeed $\mathrm{HN}$ et al. Acute and Chronic Ophthalmic Involvement in Stevens-Johnson Syndrome/Toxic Epidermal Necrolysis A Comprehensive Review and Guide to Therapy. II. Ophthalmic Disease. Ocul Surf 2016; 14: 168-88.

4. Palmieri TL, Greenhalgh DG, Saffle JR et al. A multicenter review of toxic epidermal necrolysis treated in U.S. burn centers at the end of the twentieth century. J Burn Care Rehabil 2002; 23: 87-96.

5. Sekula P. Dunant A, Mockenhaupt M et al. Comprehensive survival analysis of a cohort of patients with Stevens-Johnson syndrome and toxic epidermal necrolysis. J Invest Dermatol 2013; 133: 1197-204.

6. Bigby M, Jick S, Jick H et al. Drug-induced cutaneous reactions. A report from the Boston Collaborative Drug Surveillance Program on 15,438 consecutive inpatients, 1975 to 1982. JAMA 1986: 256: $3358-63$

7. Manriquez J, Andino-Navarrete R, Cataldo-Cerda $K$ et al. Progression of drug exanthemas to serious drug eruptions: A retrospective review identifying early determinants. Australas J Dermatol 2016: 57: e83-7. 
8. Roujeau JC, Stern RS. Severe adverse cutaneous reactions to drugs. N Engl J Med 1994; 331: $1272-85$.

9. Kohanim S, Palioura S, Saeed HN et al. StevensJohnson Syndrome/Toxic Epidermal Necrolysis A Comprehensive Review and Guide to Therapy. I. Systemic Disease. Ocul Surf 2016; 14: 2-19.

10. Garcia-Doval I, LeCleach L, Bocquet H et al. Toxic epidermal necrolysis and Stevens-Johnson syndrome: does early withdrawal of causative drugs decrease the risk of death? Arch Dermatol 2000; 136: $323-7$

11. Huang YC, Li YC, Chen TJ. The efficacy of intravenous immunoglobulin for the treatment of toxic epidermal necrolysis: a systematic review and meta-analysis. Br J Dermatol 2012; 167: 424-32.
12. Mahajan R, Kanwar AJ. Use of granulocyte colonystimulating factor in the treatment of toxic epidermal necrolysis-experience with 3 patients. Skinmed 2013; 11: 269-71.

13. Halevy S, Ghislain PD, Mockenhaupt M et al. Allopurinol is the most common cause of StevensJohnson syndrome and toxic epidermal necrolysis in Europe and Israel. J Am Acad Dermatol 2008. 58: $25-32$.

14. Stamp LK, Day RO, Yun J. Allopurinol hypersensitivity: investigating the cause and minimizing the risk. Nat Rev Rheumatol 2016: 12: 235-42.

15. Rødevand E, Sletvold O, Kvande KT. Bivirkninger av allopurinol. Tidsskr Nor Lægeforen 2004; 124 : 2618-9.

16. Ramasamy SN, Korb-Wells CS, Kannangara DR et al. Allopurinol hypersensitivity: a systematic review of all published cases, 1950-2012. Drug Saf 2013; 36: 953-80.

17. Mockenhaupt M, Viboud C, Dunant A et al. StevensJohnson syndrome and toxic epidermal necrolysis: assessment of medication risks with emphasis on recently marketed drugs. The EuroSCAR-study. J Invest Dermatol 2008; 128: 35-44.

Mottatt 4.3. 2016, første revisjon innsendt 24.6. 2016, godkjent 22.8. 2016. Redaktør: Liv-Ellen Vangsnes. 